\title{
THE OPTIMIZATION OF EMPLOYEE PERFORMANCE IMPROVEMENT REVIEWED FROM THE PERSPECTIVES OF PERFORMANCE ALLOWANCES, WORK MOTIVATION, AND WORK DISCIPLINE IN THE LPD BANYUNING, LPD LUMBANAN, LPD PADANG BULIA, LPD SARI MEKAR
}

\author{
Luh Kartika Ningsih ${ }^{1}$, Ni Luh Putu Eka Yudi Prastiwi², \\ AAN. Eddy Supriyadinata Gorda ${ }^{3^{*}}$ \\ Management, STIE Satya Dharma Singaraja, Indonesia ${ }^{1,2}$ \\ Management, Undiknas Denpasar, Indonesia ${ }^{3}$ \\ luhkartikaningsih@gmail.com ${ }^{1}$
}

\begin{abstract}
The purpose of this study was to find out how to Improve Employee Performance reviewed from the Perspectives of Performance Allowances, Work Motivation, and Work Discipline in the LPD Banyuning, LPD Lumbanan, LPD Padang Bulia, LPD Sari Mekar. This study used a quantitative approach. The data analysis technique used in the structural equation model (Structural Equation Modeling-SEM) was based on variance or component based SEM, which is famously called Partial Least Square (PLS) Visual version 3.0. All relationships examined showed positive and significant results. For this reason, in its realization, the LPD Banyuning, LPD Lumbanan, LPD Padang Bulia, LPD Sari Mekar were expected to be able to improve the performance of the Employees with the Performance Allowances. The realization of employee performance, this is also the impact of the existence of Work Motivation, Performance Allowances, and Work Discipline that will have an impact on improving employee performance in the LPD Banyuning, LPD Lumbanan, LPD Padang Bulia, LPD Sari Mekar.
\end{abstract}

Keywords: Performance Allowance; Work Motivation; Work Discipline; and Employee Performance

\section{INTRODUCTION}

Human Resources is a major component in an organization that participates in carrying out its duties, principles, functions, and all activities in it. Along with the times, each institution / agency is required to have qualified and competent human resources, so human resources need to be managed properly. Human resource management is called human resource management, the efforts of human resource management can be passed by way of developing and defending human resources that already have competence and high quality. Mustika \& Sutrisno (2016) stated that human resources are "Employees who are ready, capable and alert in achieving organizational goals. As stated in the main dimensions of the 
human resource side is its contribution to the organization, while the basic dimension of human resources is the treatment of contributions to it which in turn will determine the quality and capabilities of his life".

Performance allowances are paid according to performance achievements. The provision of performance benefits must be in line with improving employee performance. Therefore, all employees must improve integrity, discipline, work performance, cooperation among employees, and increase commitment and motivation. The amount of performance allowance is fluctuating depending on the performance of the employee concerned. This is in accordance with the opinion of Simamora (2004) which states that the principle of compensation is fair and appropriate according to the achievements and responsibilities of the employee. From a theoretical perspective, performance-based compensation is an innovative idea because this system enables organizations to drive an average level of individual work motivation, increase individual-oriented achievement and maintain high ratings for high-performing employees (Kopelman et al., 2001).

In addition to performance allowances to achieve a quality human resources can not be separated from one's motivation to work. Without positive motivation the quality itself will not be achieved. Motivation is a term that is often mentioned by superiors as leaders of an organization both openly and personally or individually. Motivation is indeed very closely related to leadership. As we have seen, there is a view of work motivation proposed by Ernest J. McCormick (1985) suggesting that (work motivation is defined as a condition that influences arousing, directing and maintaining behavior related to the work environment) (Mangkunegara, 2001).

In addition to performance allowance affect work motivation, performance benefits can also affect work discipline. In an effort to raise employee awareness, an institution leader should be aware of the needs of his employees, one of which is the institution can try to provide motivation in the form of rewards or repayments to employees who have upheld the level of discipline and work performance for the success of the institution. These rewards are stimuli that can arouse one's passion at work. In general, employees who work are satisfied to meet their daily needs, so they strive to improve work performance and discipline in a better direction. In order to be assessed and received an award. One form of appreciation that can be given is rewards / remuneration or called incentives.

According to Hasibuan (2008) discipline is one's awareness and willingness to obey all regulations in an organization and applicable social norms. Awareness is the attitude of someone who voluntarily obeys all the rules and is aware of their duties and responsibilities. Willingness is an attitude, the behavior of someone who is in accordance with organizational rules both written and unwritten. Then according to Siagian (2000) the argument that discipline is a form of training that seeks to improve and shape knowledge, attitudes, behavior voluntarily and work cooperatively with other employees and improve work performance.

To improve employee performance, there needs motivation so that employees can work well and optimally, one of them is by giving performance allowances to employees who can spur employee enthusiasm in carrying out their duties and responsibilities for their work quickly and correctly. Performance Allowance is one of the external factors that influences efforts to improve employee performance. Performance allowance is an implementation of the provision of 
compensation or appropriate compensation for work performance or performance. Or in other words the performance allowance is an award in the form of additional income given to employees for their performance with the aim of increasing employee morale. The granting of performance allowances according to Government Regulation Number 58 of 2005 concerning Regional Financial Management in Article 63 confirms "Additional income is given in the context of improving employee welfare based on work performance, place of work, working conditions and professional scarcity".

Based on observations, by looking at the frequency of attendance of employees at the Institute, that the level of employee discipline is still low. In particular some employees are seen often arriving late and committing violations such as absenteeism, or completion of breaks not according to the specified time. Even though some of the things done by the employee look like offense, but if it is not done tighter control or supervision, it will have implications for the Institute itself, for example the goals set by the Institute cannot be achieved optimally and the Institute's productivity is low.

\begin{tabular}{|c|c|c|c|c|c|}
\hline \multicolumn{6}{|c|}{$\begin{array}{c}\text { Table } 01 \\
\text { Percentage of Attendance } \\
\text { LPD Lumbanan, LPD Banyuning, LPD Sari Mekar, LPD Padang Bulia } \\
2018\end{array}$} \\
\hline No & $\begin{array}{c}\text { LPD } \\
\text { Institution }\end{array}$ & $\underset{n}{\text { Permissio }}$ & $\begin{array}{l}\text { Without } \\
\text { Informatio } \\
\text { n }\end{array}$ & Total & Percentage \\
\hline 1 & LPD Lumbanan & 40 & 19 & 59 & $70.2 \%$ \\
\hline 2 & LPD Banyuning & 30 & 15 & 45 & $46.8 \%$ \\
\hline 3 & LPD Sari Mekar & 11 & 48 & 59 & $122.9 \%$ \\
\hline 4 & $\begin{array}{l}\text { LPD Padang } \\
\text { Bulia }\end{array}$ & 89 & 60 & 149 & $124.1 \%$ \\
\hline
\end{tabular}

Source: LPD Lumbanan, LPD Banyuning, LPD Sari Mekar, LPD Padang Bulia

This research is also supported by several previous studies that have been conducted with the same problems, including:

\section{Table 02 \\ Previous Researches}

\begin{tabular}{cll|l|l} 
No & Researcher & \multicolumn{1}{c}{ Title } & \multicolumn{1}{c}{ Result Studies } \\
\hline $\mathbf{1}$ & $\begin{array}{l}\text { Graha et al. } \\
(2016)\end{array}$ & $\begin{array}{l}\text { Analysis of Culture Influence of } \\
\text { Organizations and Compensation } \\
\text { on Employee Performance with } \\
\text { Motivation as a Variable of } \\
\text { Intervening }\end{array}$ & $\begin{array}{l}\text { Compensation has a } \\
\text { positive effect on } \\
\text { motivation }\end{array}$ \\
\hline $\mathbf{2}$ & $\begin{array}{l}\text { Usmiar } \\
(2016)\end{array}$ & $\begin{array}{l}\text { The Influence of Performance } \\
\text { Allowances for Motivation of } \\
\text { Work Members of the Indonesian }\end{array}$ & $\begin{array}{l}\text { Performance Allowances } \\
\text { have a positive effect on } \\
\text { motivation }\end{array}$ \\
\hline
\end{tabular}




\begin{tabular}{|c|c|c|c|}
\hline & & $\begin{array}{l}\text { National Police and Civil } \\
\text { Servants in the State of the } \\
\text { Republic of Indonesia }\end{array}$ & \\
\hline 3 & $\begin{array}{l}\text { Suharto } \\
(2005)\end{array}$ & $\begin{array}{l}\text { The Effect of Organizational } \\
\text { Culture, Leadership and } \\
\text { Motivation on the Performance of } \\
\text { Human Resources in the Central } \\
\text { Java Provincial DPRD Secretariat } \\
\text { Work }\end{array}$ & $\begin{array}{l}\text { Motivation has a positive } \\
\text { and significant impact on } \\
\text { Employee Performance }\end{array}$ \\
\hline 4 & $\begin{array}{l}\text { Sari et al. } \\
(2012)\end{array}$ & $\begin{array}{l}\text { The Effect of Leadership, } \\
\text { Motivation, and Job Stress on } \\
\text { Employee Performance at the } \\
\text { Syariah Bank Mandiri Makassar } \\
\text { Branch Office Work }\end{array}$ & $\begin{array}{l}\text { Motivation has a positive } \\
\text { and significant impact on } \\
\text { Employee Performance }\end{array}$ \\
\hline 5 & $\begin{array}{l}\text { Dharmawan } \\
(2011)\end{array}$ & $\begin{array}{l}\text { The Effect of Compensation and } \\
\text { Non-Physical Work Environment } \\
\text { on Discipline and Performance of } \\
\text { Employees of the Nikki Hotel } \\
\text { Denpasar }\end{array}$ & $\begin{array}{l}\text { Compensation has a } \\
\text { positive and significant } \\
\text { impact on Work } \\
\text { Discipline }\end{array}$ \\
\hline 6 & $\begin{array}{l}\text { Uherman et } \\
\text { al. (2017) }\end{array}$ & $\begin{array}{l}\text { The Effect of Performance } \\
\text { Allowance and Leadership on } \\
\text { Employee Motivation at the } \\
\text { Secretariat of the Soppeng } \\
\text { Regency Election Commission }\end{array}$ & $\begin{array}{l}\text { Compensation has a } \\
\text { positive and significant } \\
\text { effect on Work Discipline }\end{array}$ \\
\hline 7 & $\begin{array}{l}\text { Setiyawan } \\
\& \text { Waridin } \\
(2006)\end{array}$ & $\begin{array}{l}\text { The Effect of Employee } \\
\text { Discipline and Employee Culture } \\
\text { on Performance in the Radiology } \\
\text { Division of RSUP Dokter Kariadi } \\
\text { Semarang }\end{array}$ & $\begin{array}{l}\text { Discipline Workers have a } \\
\text { positive effect on } \\
\text { Employee Performance }\end{array}$ \\
\hline 8 & $\begin{array}{l}\text { Satrio } \\
\text { (2009) }\end{array}$ & $\begin{array}{l}\text { The Effect of Compensation and } \\
\text { Incentives on Employee } \\
\text { Productivity in PT. Lenggogeni } \\
\text { South Jakarta }\end{array}$ & $\begin{array}{l}\text { Compensation has a } \\
\text { positive effect on work } \\
\text { productivity. }\end{array}$ \\
\hline 9 & $\begin{array}{l}\text { Kristina et } \\
\text { al. }(015)\end{array}$ & $\begin{array}{l}\text { The Influence of Employee } \\
\text { Remunization on Employee } \\
\text { Performance in the Ministry of } \\
\text { State Secretariat of the Republic } \\
\text { of Indonesia }\end{array}$ & $\begin{array}{l}\text { Performance Allowances } \\
\text { have a positive effect on } \\
\text { Employee Performance }\end{array}$ \\
\hline
\end{tabular}

Source: Article \& Journal Research

From the background and previous research that has been presented, what makes this research different from previous research is that this research was 
conducted at the Village Credit Institution (LPD) which is a financial institution where in the management of the organization is still very thick using local Indigenous Village rules and regulations (awig-awig). In addition, the concept proposed in this study is still new because it is a development of several concepts that have been studied previously by examining more complex problems.

Based on the background description above, the researcher feels interested to know the extent of the Performance Allowance, work motivation, and Work Discipline to realize the Performance of the Employees of the Banyuning LPD, Lumbanan LPD, Padang Bulia LPD and Sari Mekar LPD of Buleleng Regency. Then the following thinking framework can be formed:

\section{Framework}

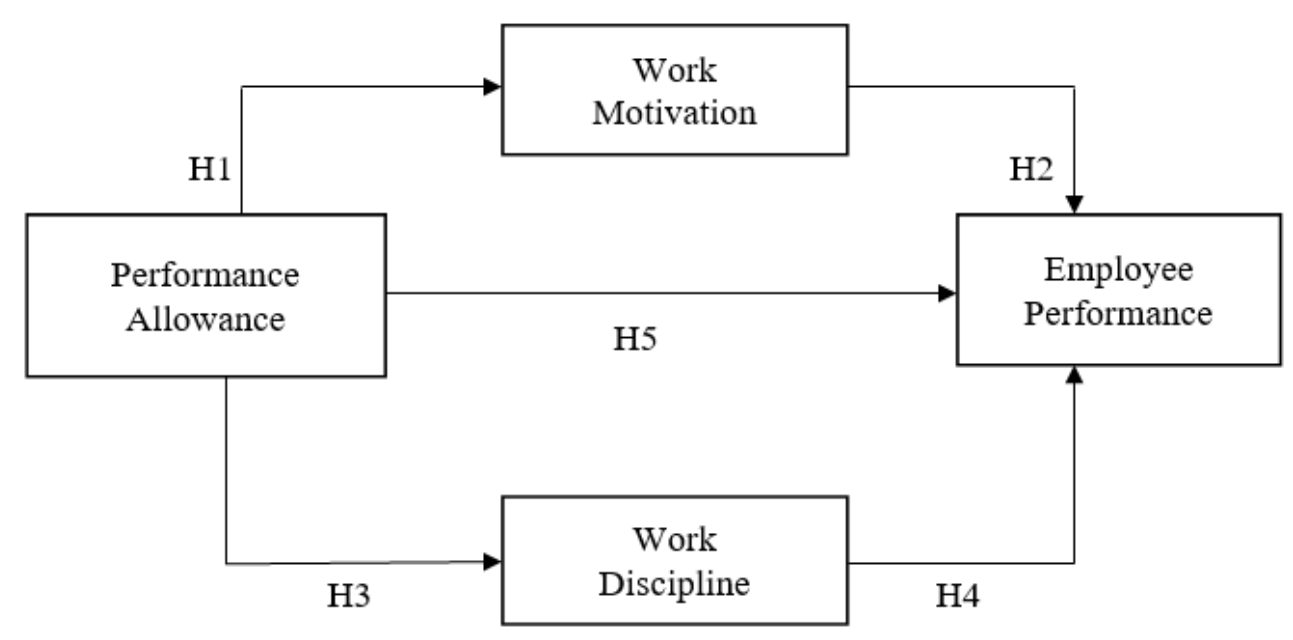

\section{METHODOLOGY}

This research uses quantitative methods using statistical test analysis tools as a tool in data processing. The data analysis technique used in this study is the structural equation model (Structural Equation Modeling-SEM) based on variance or Component based SEM, which is famously called Partial Least Square (PLS) Visual version 2.0. Analysis of research data aims to answer the problem and test the hypotheses that have been formulated. The data used in this study are questionnaire data that has been answered by respondents where later the collected data is tabulated based on each category then a statistical analysis is carried out, and for further discussion is carried out related to the analysis of the data that has been processed.

Ghozali (2011) states that PLS is a powerful analysis method, because it is not based on many assumptions, the data do not have to be multivariate normally distributed (indicators with category scales, ordinal intervals to ratios can be used on the same model), the sample does not have to be large. PLS can analyze and construct constructs with reflexive indicators and formative indicators. PLS-SEM aims to test the predictive relationship between constructs by looking at whether there is a relationship or influence between these constructs. Parameter estimates obtained with PLS can be categorized into three. The first category, is the weight estimate used to create a score of latent variables. The second reflects the path 
estimate (path estimate) that connects the latent variable and between the latent variable and the indicator block (loading). The third category is related to the means and location parameters (regression constant values) for indicators and latent variables. To obtain these three estimates, PLS uses a three-stage iteration process and each iteration stage produces an estimate. The first stage produces weight estimates, the second stage produces estimates for the inner model and outer model, and the third stage produces estimates of means and locations (constants). The evaluation of the PLS model is based on the measurement of predictions that have non-parametric properties. Therefore, the PLS evaluation model is carried out by assessing the outer model and the inner model.

\section{RESULTS AND DISCUSSION}

This study will examine the achievement of Employee Performance in Village Credit Institutions (LPD measured through the perspective of Performance Allowance, Motivation, and Work Discipline.To test this structural model and prove the hypothesis of this study using SEM-PLS analysis. Measurement models in PLS are also called outer models. Outer models define how each indicator relates to its construct (Ghazali, 2008). Evaluation of this model consists of tests of validity, reliability testing, and the significance of the indicators and visible structures.

The path analysis model of all latent variables in PLS consists of three relationships: (1) inner models that specify the relationships between latent variables (structural models), (2) outer models that specify relationships between latent variables with indicators (measurement models), and (3) weight relations and the specificity of the latent variables (structural models), (2) outer models that specify relationships between latent variables with indicators (measurement models), and (3) weight relations and the specificity of latent variables can be estimated. Without missing generalizations, it can be assumed that latent variables and indicators are on the scale of zero means and unit variance (standardized values) so that the isolation parameters (constant parameters) can be removed from the model.

\section{A. Relationship of Exogenous Constructions with Endogenous}

Constructions Evaluation of the first type of structural model is the relationship between exogenous constructs and endogenous constructs can be seen through t-statistical tests and structural path coefficients. The t-table value for the significance level $\alpha=0.05$ and degree of freedom $(\mathrm{df})=25$ is 1.078 . If t-statistics $>$ from t-tables, it can be concluded that the endogenous construct has a significant effect on the exogenous construct. The results of data processing that explains the relationship between exogenous constructs and endogenous constructs can be seen from the following table 03 : 


\section{Table 03}

Path Coefficients

\begin{tabular}{l|c|c|c|c|c} 
& $\begin{array}{c}\text { Original } \\
\text { Sample } \\
(\mathbf{O})\end{array}$ & $\begin{array}{c}\text { Sample } \\
\text { Mean } \\
(\mathbf{M})\end{array}$ & $\begin{array}{c}\text { Standard } \\
\text { Deviation } \\
(\mathbf{S T D E V})\end{array}$ & $\begin{array}{c}\text { T Statistics } \\
(|\mathbf{O} / \mathbf{S T D E V}|)\end{array}$ & $\begin{array}{c}\text { Test } \\
\text { Significance }\end{array}$ \\
\hline $\begin{array}{l}\text { Work Discipline -> } \\
\text { Employee Performance }\end{array}$ & 0,513 & 0,541 & 0,201 & 2,554 & Significant \\
\hline $\begin{array}{l}\text { Work Motivation -> } \\
\text { Employee Performance }\end{array}$ & 0,157 & 0,159 & 0,206 & 0,763 & $\begin{array}{c}\text { Not } \\
\text { Significant }\end{array}$ \\
\hline $\begin{array}{l}\text { Performance Allowance } \\
\text {-> Work Discipline }\end{array}$ & 0,678 & 0,682 & 0,109 & 6,196 & Significant \\
\hline $\begin{array}{l}\text { Performance Allowance } \\
\text {-> Employee } \\
\text { Performance }\end{array}$ & 0,266 & 0,234 & 0,155 & 1,723 & Significant \\
\hline $\begin{array}{l}\text { Performance Allowance } \\
->\text { Work Motivation }\end{array}$ & 0,718 & 0,730 & 0,085 & 8,421 & Significant \\
\hline
\end{tabular}

Source: data processed

The evaluation of the second type of structural model is the relationship between exogenous constructs by observing the $\mathrm{R} 2$ value generated through data processing. The value of $\mathrm{R} 2$ reflects the extent to which a constonexogon can explain other constonexogens. The results of the PLSR-Square present the amount of variance from the constructs explained by the model. The R-Squared Value is a test of goodness model. $\mathrm{R} 2$ value is said to be good if it has a value $>0.80$ (Wijanto, 2008).

Here is a table of relationships between endogenous constructs, which can be seen from the following table 04:

\section{Table 04 \\ R-Square}

\section{Variable}

\section{R Square}

\begin{tabular}{|l|l|}
\hline Work Discipline & 0,460 \\
\hline Employee Performance & 0,710 \\
\hline Work Motivation & 0,515 \\
\hline
\end{tabular}

Source: data processed

Table 04 shows the R-square value for the Work Discipline variable obtained at 0.460 , and for the Employee Performance variable obtained at 0.710 , for the Work Motivation variable at 0.515 . R-Squares value of $0.67 ; 0.33$ and 0.19 for endogenous latent variables in the structural model show strong, moderate, and weak models (Chin, 1998 in Latan \& Ghozali, 2012). These results indicate that $46.0 \%$ of the variable Work Discipline can be influenced by the variable Performance Allowance, Work Motivation, and Employee Performance, then the value of $71.0 \%$ Employee Performance can be influenced by the variable Work 
Discipline, Performance Allowances and Work Motivation, while the value of 51 , $5 \%$ of Work Motivation can be influenced by the Performance Allowance variable.

Table 05

Data Analysis Result

\begin{tabular}{|l|c|c|} 
& $\begin{array}{c}\text { t-Statistics } \\
(>\mathbf{1 , 0 7 8})\end{array}$ & $\begin{array}{c}\text { Significance } \\
\text { Test }\end{array}$ \\
\hline $\begin{array}{l}\text { Work Discipline -> Employee } \\
\text { Performance }\end{array}$ & 2,554 & Significant \\
\hline $\begin{array}{l}\text { Work Motivation -> Employee } \\
\text { Performance }\end{array}$ & 0,763 & Not Significant \\
\hline $\begin{array}{l}\text { Performance Allowance -> } \\
\text { Work Discipline }\end{array}$ & 6,196 & Significant \\
\hline $\begin{array}{l}\text { Performance Allowance -> } \\
\text { Employee Performance }\end{array}$ & 1,723 & Significant \\
\hline $\begin{array}{l}\text { Performance Allowance -> } \\
\text { Work Motivation }\end{array}$ & 8,421 & Significant \\
\hline
\end{tabular}

Source: data processed

Based on the above data it can be seen that from the five relationships studied there is one relationship that shows insignificant results, namely the influence of Work Motivation on Employee Performance. From the results of research and observations that have been carried out in related LPDs, motivational activities are currently not carried out consistently given the operational system of the LPD is still very simple. From the results of the questionnaire distributed also showed the results indicated by respondents were still very limited in receiving work motivation. So the results shown are not significant.

Based on the case with the results shown by the four other relationships that show significant results. Where the employees in the related LPD are indeed formed to have work discipline so that the performance of LPD employees can remain stable and maximum in providing services to the Customary Villages. In addition, the Performance Allowance is also given high attention by the LPD itself where those who are serving employees will be fulfilled to support the LPD Employee Performance. And these results are also shown from the results of the questionnaire answered by respondents according to the actual situation in their workplaces.

Based on the results of research that have been described before, there can be different results in the influence of Motivation to Work on Employee Performance. Some of the previous researches that showed positive results were significant while in this research they showed no significant results. This becomes different relationships that are tested in different places with the characteristics of different types of work. And these results will be referred to in improving employee employment in the related LPD, in order to pay more attention to the needs of employees in motivational activities so that employee performance is more maximized and is supported by Performance and Discipline Allowances. 


\section{CONCLUSION}

From the results of the research, it can be known that you still have limited LPDs related to empowering and improving the quality of work performance of employees who are still felt not to maximally in providing motivational motivation in the form of motivational activities. In order to be referred to by LPDs in order to pay more attention to the needs of employees to provide the necessary work motivation so that the performance of LPD employees can be achieved. The work discipline and performance allowances that have been given show good enough results, and can be maintained after being improved so that the quality of employee performance can be accounted for so that LPD services can maximize the safety of the community in the villages.

Researchers realize that this research is still very far from perfection, so that the next researchers can test the development of LPDs as well as develop more advanced research and development services.

\section{REFERENCES}

Dharmawan, I. M. Y. (2011). Pengaruh Kompensasi dan Lingkungan Kerja Non Fisik terhadap Disiplin dan Kinerja Karyawan Hotel Nikki Denpasar. Universitas Udayana Bali.

Ghozali, I. (2011). Structural Equation Modeling Metode Alternatif Dengan Partial Least Square (PLS) (3rd ed.). Badan Penerbit Universitas Diponegoro.

Graha, A., Christo, A. M., \& Rahardjo, E. (2016). Analisis Pengaruh Budaya Organisasi dan Kompensasi terhadap Kinerja Karyawan dengan Motivasi Sebagai Variabel Intervening (studi kasus pada PT.LG Penjualan Indonesia Semarang). Diponegoro Journal of Management, 5(2). https://ejournal3.undip.ac.id/index.php/djom/article/view/13853

Hasibuan, M. S. P. (2008). Manajemen Sumber Daya Manusia: Jakarta, Indonesia: PT. Bumi Aksara.

Kopelman, R. E., Ravenpor, J. L., \& Cayer, M. (2001). Merit pay and organizational performance: Is there an effect on the bottom line? National Productivity Review, 10(3), 299-307.

Kristina, D., Jumiati, I. E., \& Handayani, R. (2015). Pengaruh Remunerasi Pegawai Terhadap Kinerja Pegawai di Kementerian Sekretariat Negara Republik Indonesia. Universitas Sultan Ageng Tirtayasa.

Latan, H., \& Ghozali, I. (2012). Partial least Squares: Concept and application path modeling using program XLSTAT-PLS for empirical research. Badan Penerbit Universitas Diponegoro.

Mangkunegara, A. A. A. P. (2001). Manajemen sumber daya manusia perusahaan. Remaja Rosdakarya.

Mustika, F. A., \& Sutrisno, S. (2016). Model Evaluasi Kinerja Karyawan dengan Metode Fuzzy Sugeno pada Resto ABTL. STRING (Satuan Tulisan Riset Dan Inovasi Teknologi), 1(1).

Sari, R., Muis, M., \& Hamid, N. (2012). Pengaruh Kepemimpinan, Motivasi, Dan Stres Kerja Terhadap Kinerja Karyawan Pada Bank Syariah Mandiri Kantor Cabang Makassar. Jurnal Analisis, 1(1), 87-93.

Satrio, P. E. M. (2009). Pengaruh kompensasi dan insentif terhadap produktivitas kerja karyawan PT. Lenggogeni Jakarta Selatan. Universitas Guna Darma. 
Setiyawan, B., \& Waridin. (2006). Pengaruh Disiplin Kerja Karyawan Dan Budaya Organisasi Terhadap Kinerja Di Divisi Radiologi RSUP Dokter Kariadi Semarang. JRBI, 2(2), 181-198.

Siagian, S. P. (2000). Manajemen Sumber Daya Manusia. Bumi Aksara.

Simamora, H. (2004). Manajemen Sumber Daya Manusia. Balai Pustaka.

Suharto, B. C. (2005). Analisis Pengaruh Kepuasan Kerja, Motivasi dan Budaya Organisasi Terhadap Kinerja Karyawan. Jurnal Universitas Semarang.

Uherman, A., Mattalatta, \& Abdullah, R. (2017). Pengaruh Kepemimpinan Dan Tunjangan Kinerja Terhadap Motivasi Kerja Pegawai Pada Sekretariat Komisi Pemilihan Umum Kabupaten Soppeng. Jurnal Mirai Management, 2(1), 194-200.

Usmiar. (2016). Pengaruh Tunjangan Kinerja terhadap Motivasi Kerja Anggota POLRI dan Pegawai Negeri Sipil POLRI di Lingkungan Negara Republik Indonesia. E-Jurnal Menara Ilmu LPPM UMSB, 10(2).

Wijanto, S. H. (2008). Structural Equation Modeling dengan LISREL 8.8. Konsep dan Tutorial. Penerbit Graha Ilmu. 